\title{
Diabetic state-induced modification of resting membrane potential and conductance in diaphragm muscle of alloxan and diabetic KK-CA ${ }^{\mathrm{y}}$ mice
}

\author{
M. Kimura, I. Kimura, T. Nakamura and H. Nojima \\ Department of Chemical Pharmacology, Faculty of Pharmaceutical Sciences, Toyama Medical and Pharmaceutical University, Sugitani, \\ Toyama, Japan
}

\begin{abstract}
Summary. The electrical properties of skeletal muscle membranes were investigated in genetically diabetic $\mathrm{KK}-\mathrm{CA}^{y}$ mice and alloxan-induced diabetic ddY mice. Using isolated phrenic nerve-diaphragm muscle or sciatic nerve-gastrocnemius muscle in situ preparations, nerve-stimulated twitch tensions (the maximal value) were obtained at lower voltage pulse in diabetic $\mathrm{KK}-\mathrm{CA}^{y}$ mice than in normal ddY mice. The diabetic state reduced resting membrane potentials $(1.7-4.0 \mathrm{mV})$ and resting membrane conductance $(0.37$ $0.44 \mu$ siemen), decreased the amplitude $(3.8-3.9 \mathrm{mV})$ and overshoot $(4.5 \mathrm{mV})$ of directly induced-action potential, and prolonged action potential duration. In the diabetic state, resting membrane conductance was multiply-correlated with
\end{abstract}

blood glucose level and resting membrane potential. In alloxan-induced diabetic mice, resting membrane potentials were significantly multiply-correlated with the weeks elapsed after alloxan injection and blood glucose level $(p<0.01)$. Since the reduction of resting membrane potential correlated with the weeks, changes in resting membrane potential may be involved in the decrease in insulin-like growth factor action. The reduction of resting membrane conductance was correlated with the increase in blood glucose.

Key words: Diabetic skeletal muscle, resting membrane potentials, resting membrane conductance, action potentials.
Neuromyopathy in diabetes has recently attracted much attention but remains largely unclarified, particularly in terms of its involvement with muscle cells. Neuromuscular junctions in the diabetic state have been found to be hypersensitive to the depolarising neuromuscular blocking drugs succinylcholine $(\mathrm{SuCh})$ but not to $d$-tubocurarine $(d$-TC) in alloxan-induced diabetic ddY mice or in diabetic KK-CA ${ }^{y}$ mice [1] (a diabetic model resembling non-insulin-dependent diabetes mellitus) when compared with normal mice [2]. The hypersensitivity is mainly attributable to the diabetic skeletal muscle cells themselves, independent of the neuroeffector [3]. It has previously been reported that the hypersensitivity to $\mathrm{SuCh}$ is not dependent on genetic differences in muscles between ddY and KK$\mathrm{CA}^{\mathrm{y}}$ mice but on the abnormality of the neuromuscular junction induced by the diabetic state [4].

The effects of insulin on skeletal muscle, on the other hand, have been studied independently of the diabetic problem. Insulin causes hyperpolarisation in vitro application in rat extensor muscle [5], is also involved in $\mathrm{Na}$ and $\mathrm{K}$ transport [6], and increases intracellular $\mathrm{Na}$ in the hypoinsulinaemic state induced by streptozotocin or fasting [7]. These reports suggest some modification of electrical properties in diabetic skeletal muscle. However, few studies have investigated the electrical properties of cell membranes of skeletal muscles in diabetes [8]. The aim of this study was to determine abnormalities in the electrical properties of muscle membranes induced by the diabetic state and in the sensitivity of twitch responses to nerve stimulation.

\section{Materials and methods}

As diabetic models male diabetic ddY mice were used at a diabetic duration of 14 days (22-35 g body weight (BW)); blood glucose level (BG): $19.2-30.4 \mathrm{mmol} / \mathrm{l})$ and 28 days (24-36 g BW; BG: $20.9-26.8 \mathrm{mmol} / \mathrm{l}$ ) after the administration of alloxan (alloxan monohydrate, $85 \mathrm{mg} / \mathrm{kg}$, was dissolved in $0.9 \% \mathrm{NaCl}$ and injected into the tail veins of the mice). Diabetic male $\mathrm{KK}-\mathrm{CA}^{y}$ mice (5-13 months old, 28-61 g BW; BG: $13.3-28.2 \mathrm{mmol} / \mathrm{l}$ ) were also used at a diabetes duration of 3-10 months. Controls were normal male ddY mice (7-8 weeks old, $30-37 \mathrm{~g} \mathrm{BW}$ ), and prediabetic male KK-CA ${ }^{y}$ mice (10-11 weeks old, 22-40 g BW; BG: 4.66-9.55 mmol/ 1). The blood samples were obtained from the orbital vein plexus of both kinds of mice. BG levels were measured by the glucose oxidase method using a glucose analyser (Beckman, Calif, USA, Type II). Hyperglycaemia developed uniformly 1 day after alloxan application. Diabetes development in KK-CA ${ }^{y}$ mice was monitored contin- 
uously every week. The BG levels were reconfirmed just before the isolation of the muscles.

Denervation procedures were as follows: a left unilateral phrenicotomy was done by removing $1-1.5 \mathrm{~cm}$ of the phrenic nerve at the plexus cervicalis with the diabetic KK-CA ${ }^{y}$ mice under urethane $(1.7 \mathrm{~g} / \mathrm{kg} \mathrm{BW})$ anaesthesia. Then, $12-16$ days later, the denervated diaphragm muscles were isolated.

Insulin (Novo, Denmark, ultralente; bovine $40 \mathrm{U} / \mathrm{ml}$, and Novo semilente; swine $40 \mathrm{U} / \mathrm{ml}$ ), and alloxan monohydrate (Nakarai, Kyoto, Japan) were used.

\section{Twitch tension by nerve stimulation}

All mice were anaesthetised by intraperitoneal injection of urethane $(1.7 \mathrm{~g} / \mathrm{kg} \mathrm{BW})$. One end of a tracheal cannula was inserted into each mouse in situ on a warm experimental table $\left(36 \pm 1^{\circ} \mathrm{C}\right)$, and the other was connected to a Harvard rodent respirator (Type 680) operating at 170 strokes/min. The left gastrocnemius muscle was freed from the adjacent muscles, leaving the vascular vessels intact. The sciatic nerve was separated and cut off as proximally as possible, except for the branch that innervates the gastrocnemius muscle. The nerves were stimulated at $0.2 \mathrm{~Hz}$ by a square wave pulse of $1 \mathrm{~ms}$ duration. The twitch responses of the muscles were recorded with an isometric transducer (Nihon Kohden, Tokyo, Japan; SB-1T-H) on a Biophysiograph 110 system (San-ei). Each tissue was loaded with a resting force of $1 \mathrm{~g}$. Then, stimulation voltages which gave maximal twitch tensions were measured as the sensitivity.

\section{Intracellular recording technique}

After the mice were decapitated and bled, isolated hemidiaphragm muscles were removed, pinned in a muscle bath, perfused with Krebs-Henseleit solution $(136.9 \mathrm{mmol} / 1 \mathrm{NaCl}, 5.0 \mathrm{mmol} / 1 \mathrm{KCl}$, $1.2 \mathrm{mmol} / 1 \mathrm{MgSO}_{4}, 2.5 \mathrm{mmol} / 1 \mathrm{CaCl}_{2}, 15.0 \mathrm{mmol} / 1 \mathrm{NaHCO}$ and $10 \mathrm{mmol} / \mathrm{l}$ glucose; $\mathrm{pH} 7.2-7.4)$ and aerated with $95 \% \mathrm{O}_{2}$ and $5 \%$ $\mathrm{CO}_{2}$. Standard capillary electrodes (tip resistance of 5-20 M $\Omega$ ) were filled with $3 \mathrm{~mol} / 1 \mathrm{KCl}$. The membrane potentials were measured with a microelectrode amplifier (Diamedical, DPZ-16A). To obtain resting membrane conductance, they were held at $-90 \mathrm{mV}$ and then voltages were clamped at a duration of $300 \mathrm{~ms}$ and sampling rate of $5 \mathrm{KHz}$ by the single electrode voltage-clamp method $[9,10]$ using a voltage-clamp amplifier (Diamedical, DPZ-30). Resting membrane conductance was calculated from the slopes of a straight line of the currents between holding potentials and $-120 \mathrm{mV}(30 \mathrm{mV}$ negative to the holding potential $-90 \mathrm{mV})[11,12]$. In voltage clamp experiments, membrane potentials and membrane currents were recorded using Visilight (Nihon-electric San-ei, Tokyo, Japan; 5M21). Action potentials elicited by passing a depolarising pulse $(0.05 \mathrm{~ms})$ via a microelectrode were recorded by another electrode inserted into the same fibre, with a signal processor (San-ei, 7T-07A) and a X-Y recorder (San-ei, 8U11).

\section{Statistical analysis}

Significant differences were analysed using unpaired Student's t-tests between twitch tensions of diabetic and non-diabetic muscles. A multiple correlation was analysed among BG levels, weeks elapsed after alloxan injection, resting membrane potentials (RMP) and resting membrane conductances $\left(\mathrm{g}_{\mathrm{m}}\right)$ as shown in footnote of Table 3 .

\section{Results}

\section{Sensitivity of diabetic neuromuscular junction to indirect stimulation}

The sensitivity of the neuromuscular junction in situ to nerve stimulation was compared between non-diabetic
Table 1. Sensitivity to indirect stimulation of isolated preparations of phrenic nerve diaphragm muscle, and in situ preparations of sciatic nerve gastrocnemius muscle in diabetic and normal mice

\begin{tabular}{|c|c|c|c|}
\hline \multirow[b]{2}{*}{ Isolated } & \multirow[b]{2}{*}{$\begin{array}{l}\text { ddY } \\
\text { Diabetic KK-CA }{ }^{y c} \\
\text { Aged dd } Y^{d}\end{array}$} & \multicolumn{2}{|c|}{ Stimulation voltage $(\mathrm{V})^{\mathrm{a}}$} \\
\hline & & $\begin{array}{cc}0.33 \pm 0.02 & (22)^{b} \\
0.30 \pm 0.03 & (20) \\
0.59 \pm 0.08 & (4)\end{array}$ & NS \\
\hline In situ & $\begin{array}{l}\text { ddY } \\
\text { Diabetic KK-CA }\end{array}$ & $\begin{array}{l}0.38 \pm 0.02 \\
0.33 \pm 0.02\end{array}$ & e \\
\hline
\end{tabular}

a This voltage gave the maximal twitch tension in skeletal muscles indirectly stimulated at $0.2 \mathrm{~Hz}$ and $1 \mathrm{~ms}$; balues are means \pm SEM (in parentheses, the number of mice); ${ }^{\circ} 5-13$ months;

d 4 months; ${ }^{\mathrm{e}} p<0.05$ (one-tail Student's t-test)

Table 2. The resting membrane potential (RMP) and resting membrane conductance $\left(\mathrm{g}_{\mathrm{m}}\right)$ in diaphragm muscles of normal, diabetic (alloxan and $\mathrm{KK}-\mathrm{CA}^{y}$ ), and denervated mice

\begin{tabular}{|c|c|c|c|c|}
\hline Mice & $\begin{array}{l}\text { Blood glucose } \\
\text { level }(\mathrm{mmol} / \mathrm{l})\end{array}$ & $\mathrm{RMP}(\mathrm{mV})$ & $\begin{array}{l}\mathrm{g}_{\mathrm{m}}{ }^{\mathrm{a}} \\
(0.1 \mu \text { siemen })\end{array}$ & $\begin{array}{l}n^{\mathrm{b}} \\
\text { (Tissue/ } \\
\text { cell) }\end{array}$ \\
\hline $\begin{array}{l}d d Y \\
\text { Non-diabetic } \\
\text { Alloxan-diabetic }\end{array}$ & $3.89-7.88$ & $-76.5 \pm 0.3^{\mathrm{c}}$ & $3.10 \pm 0.03^{c}$ & $21 / 427$ \\
\hline $\begin{array}{l}2 \text { weeks-elapse } \\
4 \text { weeks-elapse }\end{array}$ & $\begin{array}{l}19.2-30.4 \\
20.9-26.8\end{array}$ & $\begin{array}{l}-74.2 \pm 0.2 \\
-72.5 \pm 0.7\end{array}$ & $\begin{array}{l}2.90 \pm 0.03 \\
2.73 \pm 0.07\end{array}$ & $\begin{array}{c}14 / 210 \\
4 / 60\end{array}$ \\
\hline $\begin{array}{l}K K-C A^{\prime} \\
\text { Prediabetic } \\
\text { Diabetic }\end{array}$ & $\begin{array}{l}4.66-9.55 \\
11.1-27.8\end{array}$ & $\begin{array}{l}-74.6 \pm 0.4 \\
-73.2 \pm 0.3\end{array}$ & $\begin{array}{l}3.17 \pm 0.07 \\
2.93 \pm 0.03\end{array}$ & $\begin{array}{r}7 / 105 \\
28 / 456\end{array}$ \\
\hline $\begin{array}{l}d d Y \\
\text { Non-diabetic } \\
\text { denervated }^{d}\end{array}$ & & $-58.9 \pm 1.4$ & & $7 / 105$ \\
\hline $\begin{array}{l}K K-C A^{r} \\
\text { Diabetic } \\
\text { denervated }^{d}\end{array}$ & $11.1<$ & $-62.7 \pm 0.5$ & & $6 / 90$ \\
\hline
\end{tabular}

${ }^{a}$ Resting membrane conductances were measured at $-30 \mathrm{mV}$ negative voltage from the holding potential. Holding potential $=-90 \mathrm{mV}$; ${ }^{\mathrm{b}}$ Observation numbers; ${ }^{c}$ Values are means \pm SEM; ${ }^{\mathrm{d}} 12-16$ day-phrenicotomy

Table 3. Multiple correlation coefficients in blood glucose level (BG), weeks after alloxan injection (W), resting membrane potential (RMP) and resting membrane conductance $\left(\mathrm{g}_{\mathrm{m}}\right)$ in diaphragm muscles of diabetic and normal mice

\begin{tabular}{llc}
\hline Mice & & $\begin{array}{l}\text { Multiple } \\
\text { correlation } \\
\text { coefficient }\end{array}$ \\
\hline Alloxan-diabetic ddY & $\mathrm{g}_{\mathrm{m}}(\mathrm{BG}, \mathrm{RMP})^{\mathrm{a}}$ & $0.227^{\mathrm{c}}$ \\
& $\mathrm{g}_{\mathrm{m}}(\mathrm{W})^{\mathrm{b}}$ & $-0.202^{\mathrm{c}}$ \\
& $\mathrm{RMP}(\mathrm{BG}, \mathrm{W})$ & $0.250^{\mathrm{c}}$ \\
RMP $(\mathrm{W})$ & $0.249^{\mathrm{c}}$ \\
& Riabetic KK-CA & $0.226^{\mathrm{c}}$ \\
& $\mathrm{g}_{\mathrm{m}}$ (BG, RMP) & $-0.206^{\mathrm{c}}$ \\
& $\mathrm{g}_{\mathrm{m}}$ (BG) & $0.106^{\mathrm{c}}$ \\
\hline
\end{tabular}

a For three kinds of valuables $x_{1}, x_{2}$, and $x_{3}$, if $x_{1}$ is multiplycorrelated with $x_{2}$ and $x_{3}$ by the eq. (1),

$\mathrm{x}_{1}=\mathrm{a}_{1}+\mathrm{b}_{12} \mathrm{x}_{2}+\mathrm{b}_{13} \mathrm{x}_{3}$

a multiple correlation coefficient $r_{1,23}$ is calculated from the

eq. (2) (for example, $x_{1}=g_{m}, x_{2}=B G$, and $x_{3}=R M P$ )

$\left(r_{1.23}\right)^{2}=1-(\mathrm{N}-1) \mathrm{V}_{\mathrm{R}} / \mathrm{S}_{11}$

$\mathrm{V}_{\mathrm{R}}=\left(\mathrm{S}_{11}-\mathrm{b}_{12} \mathrm{~S}_{12}-\mathrm{b}_{13} \mathrm{~S}_{13}\right) /(\mathrm{N}-3)$

$\mathrm{S}_{\mathrm{ij}}=\Sigma \mathrm{x}_{\mathrm{i}} \mathrm{y}_{\mathrm{j}}, \mathrm{S}_{\mathrm{ij}}=\Sigma\left(\mathrm{x}_{\mathrm{i}}-\overline{\mathrm{x}}_{\mathrm{i}}\right)^{2}$

${ }^{b}$ if $x_{1}$ is simply correlated with $x_{2}$,

$r_{12}{ }^{2}=\left(\mathrm{S}_{12}\right)^{2} / \mathrm{S}_{11} \mathrm{~S}_{22}$

c $p<0.01$ (one-tail Student's t-test) 
ddY and diabetic $\mathrm{KK}-\mathrm{CA}^{\mathrm{y}}$ mice. In isolated phrenic nerve-diaphragm muscle preparations, the sensitivity in diabetic $\mathrm{KK}-\mathrm{CA}^{y}$ mice (displaying hyperglycaemia 15-20 weeks after birth) was slightly higher than in normal (non-diabetic) ddY mice, but the difference was not significant (Table 1). These results tended to be independent of age (4 months old) because the sensitivity of the older ddY mice was lower than that of the normal ddY mice. These results in situ preparations indicate that the higher sensitivity to indirect stimulation may be induced by the diabetic state. In the sciatic nerve-gastrocnemius muscle junction in situ, maximal twitch tensions were recorded as significantly lower voltage pulses in diabetic $\mathrm{KK}-\mathrm{CA}^{y}$ mice than in normal ddY mice, indicating that the sensitivity of diabetic neuromuscular junction to indirect stimulation was higher than that of normal muscle.

\section{Resting membrane potentials and conductance of cellular membrane of diabetic diaphragm muscle}

Resting membrane potential (RMP) and conductance $\left(\mathrm{g}_{\mathrm{m}}\right)$ were measured in diabetic diaphragm muscles. The RMP tended to decrease with time after alloxan treatment. The same results were obtained in the muscles of diabetic KK-CA ${ }^{\mathrm{y}}$ mice (Table 2).

In diaphragm muscles of alloxan-diabetic insulintreated control mice, RMP and $\mathrm{g}_{\mathrm{m}}$ were measured. At the third week after the administration of alloxan to ddY mice (5 weeks old), insulin (swine; $60 \mathrm{U} / \mathrm{kg}+$ bovine; $100 \mathrm{U} / \mathrm{kg}$ ) was applied subcutaneously every day for 8 days. Despite the recovery of BG levels, the RMP $(70.7 \pm 0.4 \mathrm{mV}, n=3 / 77)$ and the $\mathrm{g}_{\mathrm{m}}((2.6 \pm$ $0.09) \times 0.1 \mu$ semen, $n=3 / 39)$ still remained at the abnormal values.

Denervation shifted the RMP to $-58.9 \pm 1.4 \mathrm{mV}$ in non-diabetic ddY mice, and to $-62.7 \pm 0.5 \mathrm{mV}$ in diabetic KK-CA ${ }^{y}$ mice. The reduction of RMP in diabetic mice tended to be smaller than that in non-diabetic mice. These results suggest that the decreased RMP in diabetic $\mathrm{KK}-\mathrm{CA}^{y}$ mice may be attributed to the dysfunction of some neurotrophic factor. The resting membrane conductance in diaphragm muscles also tended to decrease in alloxan mice as well as diabetic $\mathrm{KK}-\mathrm{CA}^{y}$ mice when compared with that of non-diabetic mice. In the diabetic mice, $\mathrm{g}_{\mathrm{m}}$ was measured from the traces, as shown in Figure 1. The extent of reduction increased gradually with the increase in blood glucose levels.

\section{Correlation analysis of resting membrane potentials and conductance with blood glucose level or diabetic} durations

Whether the reduction in RMP and $g_{m}$ was dependent on the blood glucose level was examined by regression analysis.

In a single correlation analysis of two parameters, alloxan diabetic mice showed that RMP values were

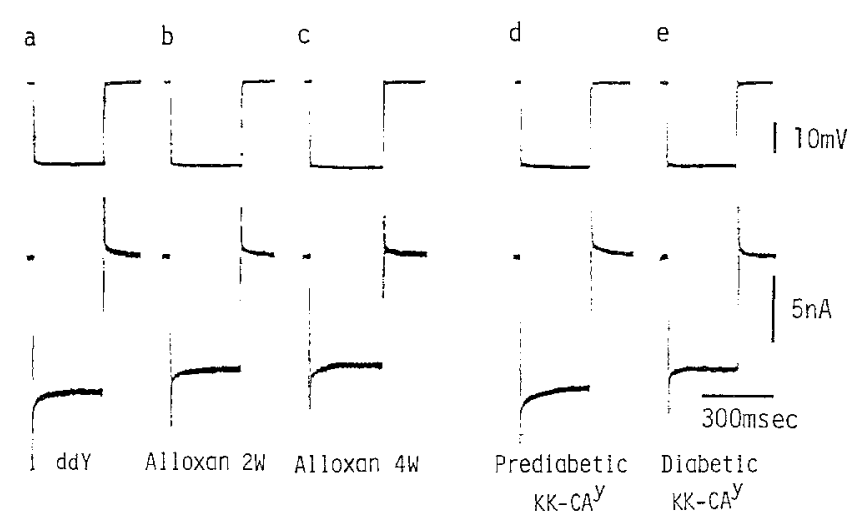

Fig.1a-e. Typical records of membrane potential and membrane current in diaphragm muscles of diabetic and non-diabetic male mice. Upper trace in each panel: clamp pulse $(-30 \mathrm{mV})$, duration $(300 \mathrm{~ms})$. Lower trace: membrane current. a non-diabetic ddY mouse, b alloxan-diabetic ddY mouse ( 2 weeks duration), c alloxandiabetic ddY mouse (4 weeks duration), d prediabetic KK-CA ${ }^{y}$ mouse and e diabetic KK-CA ${ }^{y}$. Holding potential $=-90 \mathrm{mV}$
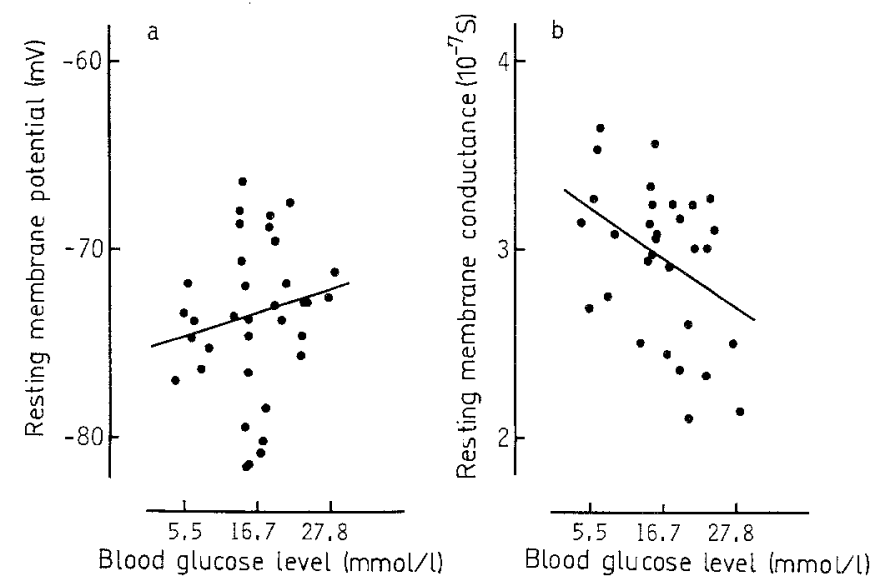

Fig. 2a and b. The relationship of resting membrane potentials (RMP) (left, a) or resting membrane conductance $\left(\mathrm{g}_{\mathrm{m}}\right)$ (right, b) with blood glucose level (BG) in diaphragm muscles of $\mathrm{KK}^{-\mathrm{CA}^{y}}$ male mice. Data were obtained from prediabetic and diabetic $\mathrm{KK}-\mathrm{CA}^{\mathrm{y}}$ male mice $(n=35 / 561)$ and averaged in each preparation

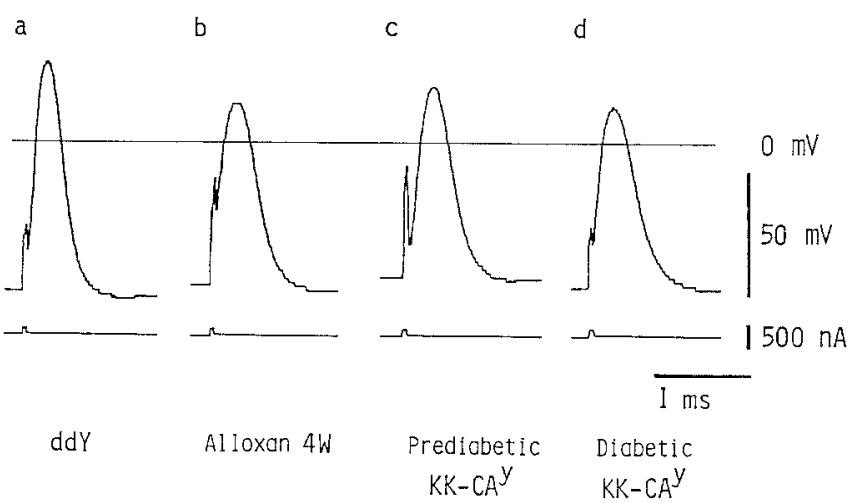

Fig.3a-d. Typical records of directly elicited action potential (AP). a non-diabetic ddY mouse, b alloxan-diabetic ddY $(4 \mathrm{~W})$, c prediabetic KK-CA ${ }^{y}$ mouse and d diabetic KK-CA ${ }^{y}$ mouse. Horizontal line represents zero potential. Lower traces show constant current (100-300 nA, $0.05 \mathrm{~ms})$ stimulation 
Table 4. Action potential (AP) characteristics in diaphragm muscles in diabetic and normal mice

\begin{tabular}{|c|c|c|c|c|}
\hline Mice & $\begin{array}{l}\text { Half- } \\
\text { amplitude } \\
\text { duration }^{\mathrm{a}} \\
\text { (ms) }\end{array}$ & $\begin{array}{l}\text { AP } \\
\text { Amplitude } \\
\text { (mV) }\end{array}$ & $\begin{array}{l}\text { AP } \\
\text { Overshoot } \\
\text { (mV) }\end{array}$ & $\begin{array}{l}\mathrm{n}^{\mathrm{b}} \\
\text { (Tissue/ } \\
\text { cell) }\end{array}$ \\
\hline \multicolumn{5}{|l|}{ ddY } \\
\hline Non-diabetic & $0.37 \pm 0.01^{\mathrm{c}}$ & $81.2 \pm 1.5$ & $22.7 \pm 1.1$ & $7 / 30$ \\
\hline $\begin{array}{l}\text { Alloxan-diabetic } \\
4 \text { weeks-elapsed }\end{array}$ & $0.46 \pm 0.02^{\mathrm{e}}$ & $77.3 \pm 1.8$ & $18.2 \pm 1.2^{\mathrm{e}}$ & $9 / 29$ \\
\hline \multicolumn{5}{|l|}{$\mathrm{KK}-\mathrm{CA}^{y}$} \\
\hline Prediabetic & $0.45 \pm 0.02$ & $81.4 \pm 2.4$ & $23.7 \pm 1.3$ & $8 / 21$ \\
\hline Diabetic & $0.46 \pm 0.01$ & $77.6 \pm 2.7$ & $19.2 \pm 1.9^{d}$ & $4 / 23$ \\
\hline
\end{tabular}

a The width of AP at a half height of the peak signal; ${ }^{b}$ Observation numbers; ${ }^{\mathrm{c}}$ Values are means $\pm \mathrm{SEM} ;{ }^{\mathrm{d}} p<0.05,{ }^{\mathrm{e}} p<0.01$, compared with non-diabetic control in each strain of mice

positively correlated with the weeks elapsed after administration of alloxan (Table 3 ). $\mathrm{g}_{\mathrm{m}}$ values were also significantly negatively correlated to weeks elapsed $(p<0.01)$ (Table 3). For $\mathrm{BG}$ in diabetic $\mathrm{KK}-\mathrm{CA}^{\mathrm{y}}$ mice, the correlation of RMP or $\mathrm{g}_{\mathrm{m}}$ values was significantly positive or negative (Figs. $2 \mathrm{a}, \mathrm{b})(p<0.01)$. The correlation coefficient $(r)$ in the single correlations indicated that RMP changes correlated slightly more closely with weeks elapsed than $g_{m}$, whereas $g_{m}$ changes were more closely correlated to BG than weeks elapsed. Furthermore, multiple correlation coefficients of diabetes-induced parameter changes were calculated (Table 3 ). In both diabetic models, $\mathrm{g}_{\mathrm{m}}$ values were significantly correlated with both $\mathrm{BG}$ and RMP $(p<0.01)$. In alloxan-induced diabetic mice, RMP values were multiply correlated with $\mathrm{BG}$ and the duration of diabetes after the application of alloxan.

\section{Action potential of diaphragm muscle in diabetic state}

Directly elicited action potentials (AP) were recorded to compare the difference between non-diabetic and diabetic skeletal muscles (Fig. 3). AP amplitude and overshoot were decreased in the diabetic state induced by alloxan, whereas the half-amplitude duration was increased. The same results were obtained in diabetic KK-CA ${ }^{y}$ mice. The diabetic state-induced change of AP amplitude, overshoot and prolongation of duration may depend on the depression of sodium currents and potassium currents (Table 4).

\section{Discussion}

The evidence obtained in the present study indicated that the electrical properties of skeletal muscle cellular membranes were modified by the diabetic state. In the twitch responses, diabetic muscles showed rather higher sensitivity to nerve-stimulation than non-diabetic muscles. The results were more significant for in situ than for in vitro experiments. The difference may be more or less dependent on the difference in prepara- tions between gastrocnemius and diaphragm muscles, because acetylcholine (ACh) inhibitor is stronger for gastrocnemius than diaphragm muscles. In a previous report [2], diabetic state-induced hypersensitivity of skeletal muscle to $\mathrm{ACh}$ applied in vitro was explained by $\mathrm{ACh}$ activity induced by indirect stimulation.

Diabetic polyneuropathy is probably caused secondarily by damage due to diabetic metabolic disorders, as reviewed by Clements [13]. This means that abnormal function of the neuromuscular junction may be dependent on the damage to nerve conduction. Our results, however, did not support this. Although the diabetic state decreased RMP of skeletal muscle cellular membranes, the present data demonstrated that the decrease in RMP had been caused in the abnormal neuromuscular junction before RMP was decreased by denervated diaphragm muscles. This result corresponded to the previous finding that the hypersensitivity in diabetic muscles was not due to denervation supersensitivity [2] and was also supported by the recent report that the modification of intracellular $\mathrm{Ca}^{2+}$ transient for the external $\mathrm{Ca}^{2+}$-free medium was different between diabetic and denervated muscles [14]; these phenomena may be contributed to by myoinositol-mediated effects.

In alloxan-diabetic insulin-treated control mice, these abnormalities concerning RMP and $\mathrm{g}_{\mathrm{m}}$ did not recover to the normal level despite the recovery of $\mathrm{BG}$ levels. However, these results are considered to be due not to some extrapancreatic toxic side effects of alloxan, because the abnormality occurred also in genetically diabetic $\mathrm{KK}-\mathrm{CA}^{y}$ male mice.

In the electrophysiological modification of diaphragm muscles by the diabetic state, $\mathrm{g}_{\mathrm{m}}$ as well as RMP decreased with the increase in blood glucose levels. The correlations between $\mathrm{g}_{\mathrm{m}}$ and RMP and the duration of diabetes after alloxan injection were both significant. The multiple correlation coefficient of RMP against BG and weeks elapsed was a significant 0.250 , and was a fairly good approximation of the single correlation coefficient of 0.249 between RMP and weeks elapsed. The results indicate that the modification of RMP was influenced by weeks elapsed rather than by blood glucose. Because blood glucose attains the submaximal level one week after alloxan injection, to be followed by a gradual increase, diabetic duration is considered to indicate the degree of shortage of blood insulin levels. The shortage of insulin, therefore, may cause the decrease of RMP in diabetic muscles, because insulin causes the hyperpolarisation and activation of the Na-K pump $[6,7]$.

Grossie [8] suggested that the reduction of RMP in alloxan-induced diabetic rat extensor muscle might involve the $\mathrm{Cl}^{-}$ion, because RMP of rat extensor muscles was sensitive to external $\mathrm{Cl}^{-}$. RMP of diaphragm muscles, however, were not affected by $\mathrm{Cl}^{-}$[15]. On the other hand, the decreased RMP could also be explained by a defective potassium conductance $\left(\mathrm{g}_{\mathrm{K}}\right)$. 
Grossie [8] reported that $\mathrm{g}_{\mathrm{K}}$ tended to decrease in diabetic muscles. In the present study also, the reduction of $g_{m}$ was correlated with $B G$, but not so with weeks elapsed. This suggests that the change in $\mathrm{g}_{\mathrm{m}}$ may be involved in the glycosylation of skeletal muscles. Nonenzymatic glycosylation mechanisms of cell membrane proteins may play a role in the alteration of electrical properties of skeletal muscles. It is not the insulin deficiency only that may alter these activities in longer lasting hyperglycaemic states.

The amplitude and the overshoot of the action potentials of diabetic muscles decreased, but the duration was prolonged. The decreases in action potential amplitude may be explained as follows: both the elevation of intracellular $\mathrm{Na}$ in diabetic muscles and the decrease in RMP might result in the decrease of driving force for $\mathrm{Na}$ across the plasma membrane, as reported by Moore [7]. Prolonged action potential duration may be involved in the decrease in $\mathrm{K}$ conductance in the diabetic state. On the other hand, Sterns [16] also reported that insulin facilitates net cellular potassium uptake; and inadequate circulating insulin levels are an important feature of the abnormal internal potassium balance that occurs in at least some diabetic patients. Changes in the action potential, membrane depolarisation and increase in $R_{m}$ (decrease in $g_{m}$ ) were frequently observed with denervation [17-19]. These features are partially shared by the diabetic state. Therefore, the modification of diabetic muscles may be involved in the decrease in insulin $\mathrm{K}^{+}$-modulating action due to insulin deficiency.

Acknowledgements. This work was supported in part by a Scientific Research Grant (No.61571093) from the Ministry of Education, Science, and Culture, Japan.

\section{References}

1. Kimura M, Suzuki J, Amemiya K (1979) A genetically diabetic model "KK-CAy mice" for a pharmacological assay. Endocrinol Jpn 26: 185-195

2. Kimura M, Kimura I, Nojima H, Muroi M (1986) Diabetes mellitus-induced hypersensitivity of mouse skeletal muscles to acetylcholine and succinylcholine. Jpn J Pharmacol 40: 251-256

3. Kimura M, Fujihara M, Nojima H, Kimura I (1986) Hypersensitivity of acetylcholine in diabetic skeletal muscle to neuromuscular blockers: the effect on myotubes cultured with spinal cord or its extract. J Pharmacobiodyn 9: 29-38

4. Fujihara M, Kimura I, Nakamura T, Kimura M (1986) Developmentally delayed sensitivity of acetylcholine receptor in myo- tubes of nerve-muscle cocultures from genetically diabetic mouse embryos. J Pharmacobiodyn 9: 402-408

5. Zierler KL (1959) Effect of insulin on membrane potential and potassium content of rat muscle. Am J Physiol 197: 515-523

6. Clausen T, Kohn PG (1977) The effect of insulin on the transport of sodium and potassium in rat soleus muscle. J Physiol (Lond) 265: $19-42$

7. Moore RD, Munford JW, Pillsworth TJ Jr (1983) Effects of streptozotocin diabetes and fasting on intracellular sodium and adenosine triphosphate in rat soleus muscle. $\mathbf{J}$ Physiol (Lond) 338: 277-294

8. Grossie J (1982) Contractile and electrical characteristics of extensor muscle from alloxan-diabetic rats. An in vitro study. Diabetes 31: 194-202

9. Tokimasa T (1985) Intracellular Ca-ions inactivate K-current in bullfrog sympathetic neurons. Brain Res 337: 386-391

10. Wilson WA, Goldner MM (1975) Voltage clamping with a single microelectrode. J Neurobiol 6: 411-422

11. Rudel R, Lehmann-Horn F, Ricker K, Kuther G (1984) Hypokalemic periodic paralysis: in vitro investigation of muscle fiber membrane parameters. Muscle Nerve 7: 110-120

12. Stanfield PR (1970) The differential effects of tetraethylammonium and zinc ions on the resting conductance of frog skeletal muscle. J Physiol (Lond) 209: 231-256

13. Clements RS Jr (1979) Diabetic neuropathy - New concepts of its etiology. Diabetes 28: 604-611

14. Kimura I, Kimura M, Kimura M (1987) $\mathrm{Ca}^{2+}$ transients modified by diabetes and denervation in mouse diaphragm muscles stimulated directly. Proceedings of the International Symposium on Polyol Pathway and its Role in Diabetic Complications. Kashikojima, Japan, 1986. Excerpta Medica, Amsterdam

15. Dulhunty AF (1978) The dependence of membrane potential on extracellular chloride concentration in mammalian skeletal muscle fibers. J Physiol (Lond) 276: 67-82

16. Sterns RH, Cox M, Feig PU, Singer I (1981) Internal potassium balance and the control of the plasma potassium concentration. Medicine 60: 339-354

17. Albuquerque EX, Thesleff S (1968) A comparative study of membrane properties of innervated and chronically denervated fast and slow skeletal muscles of the rat. Acta Physiol Scand 73: 471- 480

18. Bray JJ, Hawken MJ, Hubbard JI, Pockett S, Wilson L (1976) The membrane potential of rat diaphragm muscle fibers and the effect of denervation. J Physiol (Lond) 255: 651-667

19. Lorkovic H, Tomanek RJ (1977) Potassium and chloride conductances in normal and denervated rat muscles. Am J Physiol 232: C109-C114

Received: 2 June 1987

and in revised form: 1 December 1987

Dr. M. Kimura

Department of Chemical Pharmacology

Toyama Medical and Pharmaceutical University

2630 Sugitani

Toyama $930-01$

Japan 